\title{
Tetrahydrobiopterin Alters Superoxide and Nitric Oxide Release in Prehypertensive Rats
}

\author{
Francesco Cosentino, ${ }^{*}$ Stephen Patton, ${ }^{\S}$ Livius V. d’Uscio, ${ }^{\star}$ Ernst R. Werner," Gabriele Werner-Felmayer, $\|$ Pierre Moreau, ${ }^{\star}$ \\ Tadeusz Malinski, ${ }^{\S}$ and Thomas F. Lüscher* \\ *Cardiology and Cardiovascular Research, University Hospitals, 3010 Bern and 8091 Zürich, Switzerland; ${ }^{\ddagger}$ IRCCS Neuromed, Pozzilli, \\ Italy 86077; ${ }^{\S}$ Department of Chemistry and Institute of Biotechnology, Oakland University, Rochester, Michigan 48309-4401; "Institute of \\ Medical Chemistry and Biochemistry, Innsbruck University, Innsbruck, Austria 6020
}

\begin{abstract}
Constitutive nitric oxide synthase (cNOS) with insufficient cofactor (6R)-5,6,7,8-tetrahydrobiopterin $\left(\mathrm{H}_{4} \mathrm{~B}\right)$ may generate damaging superoxide $\left(\mathrm{O}_{2}^{-}\right)$. This study was designed to determine whether cNOS-dependent generation of $\mathrm{O}_{2}^{-}$occurs in spontaneously hypertensive rats (SHR) before the onset of hypertension. Aortas from 4-wk-old SHR and Wistar-Kyoto rats were used. cNOS was stimulated by calcium ionophore A23187. In situ measurements of nitric oxide and hydrogen peroxide by electrochemical sensors and $\mathrm{O}_{2}^{-}$production by chemiluminescence method were performed. Isometric tension was continuously recorded. $\mathrm{H}_{4} \mathrm{~B}$ by high performance liquid chromatography and $\left[{ }^{3} \mathrm{H}\right]$ citrulline assay were determined in homogenized tissue. The A23187-stimulated production of $\mathrm{O}_{2}^{-}$and its superoxide dismutase product hydrogen peroxide were significantly higher, whereas nitric oxide release was reduced in SHR aortas, with opposite results in the presence of exogenous $\mathrm{H}_{4} \mathrm{~B}$. Furthermore, $N^{\mathrm{G}}$-monomethyl-L-arginine inhibited the generation of cNOS-dependent $\mathrm{O}_{2}^{-}$by $\sim 70 \%$. Natural $\mathrm{H}_{4} \mathrm{~B}$ levels were similar in both strains; however, equivalent cNOS activity required additional $\mathrm{H}_{4} \mathrm{~B}$ in SHR. The endothelium-dependent relaxations to A23187 were significantly inhibited by catalase, and enhanced by superoxide dismutase, only in SHR; however, these enzymes had no effect in the presence of $\mathrm{H}_{4} \mathrm{~B}$. Thus, dysfunctional cNOS may be a source of $\mathrm{O}_{2}{ }^{-}$in prehypertensive SHR and contribute to the development of hypertension and its vascular complications. (J. Clin. Invest. 1998. 101:1530-1537.) Key words: nitric oxide synthase $\bullet$ hydrogen peroxide $\bullet$ SOD $\bullet$ catalase $\bullet$ aorta
\end{abstract}

\section{Introduction}

The endothelium modulates vascular tone through the release of nitric oxide (NO), ${ }^{1}$ a potent vasodilator that regulates blood

This work was presented in part at the 50th Annual Fall Conference and Scientific Sessions of the Council for High Blood Pressure Research, Chicago, Illinois, 1998.

Address correspondence to Tadeusz Malinski, Ph.D., Department of Chemistry and Institute of Biotechnology, Oakland University, Rochester, MI 48309-4401. Phone: 810-370-2339; FAX: 810-3702321.

Received for publication 15 May 1997 and accepted in revised form 21 January 1998.

J. Clin. Invest.

(C) The American Society for Clinical Investigation, Inc. 0021-9738/98/04/1530/08 \$2.00

Volume 101, Number 7, April 1998, 1530-1537

http://www.jci.org pressure and regional blood flow (1-4). Existing evidence suggests that the enzymatic pathway for the production of NO is impaired in the vascular endothelium of spontaneously hypertensive rats (SHR) or patients with essential hypertension (58). In normotensive mammalian tissue, constitutive nitric oxide synthase (cNOS) in the presence of sufficient cofactor (6R)-5,6,7,8-tetrahydrobiopterin $\left(\mathrm{H}_{4} \mathrm{~B}\right)$ receives and stores enough electrons from nicotinamide adenine dinucleotide phosphate (NADPH) to transform the cosubstrates $\mathrm{O}_{2}$ and L-arginine into the products $\mathrm{NO}$ and L-citrulline (9). It has been demonstrated in vitro $(9,10)$ that $\mathrm{H}_{4} \mathrm{~B}$-deficient isolated cNOS, when activated, cannot catalyze the five electron oxidation of L-arginine into NO. However, the same $\mathrm{H}_{4} \mathrm{~B}$-deficient cNOS can still receive electrons from NADPH and store them in its bound flavins, and then can donate them one-at-a-time to its other substrate, $\mathrm{O}_{2}$, resulting in one electron reduction to form superoxide anion $\left(\mathrm{O}_{2}{ }^{-} ; \mathrm{pK}_{\mathrm{a}}=4.8\right)$. The precise role of $\mathrm{H}_{4} \mathrm{~B}$ in regulation of cNOS catalytic activity is still not completely understood $(11,12)$. However, these findings suggest that $\mathrm{H}_{4} \mathrm{~B}$ is allosterically involved in the coupling of the oxidase and reductase domains of cNOS within the active dimer.

Interestingly, an impaired synthesis of $\mathrm{H}_{4} \mathrm{~B}$ occurs in adrenal cortex of SHR (13). This metabolic dysfunction was detected in prehypertensive animals suggesting that it may contribute to the development of hypertension and its complications. Recently, we reported that $\mathrm{H}_{2} \mathrm{O}_{2}$ formed via cNOS becomes a mediator of endothelium-dependent relaxations in intact coronary arteries depleted of $\mathrm{H}_{4} \mathrm{~B}$ (14). Whereas $\mathrm{O}_{2}^{-}$is a potent mediator of endothelium-dependent contraction (15), $\mathrm{H}_{2} \mathrm{O}_{2}$ is a potent vasodilator (14). Since aortic tissue naturally contains superoxide dismutase (SOD; $1-5 \times 10^{-6} \mathrm{~mol} / \mathrm{liter}$ ), an enzyme that rapidly converts $\mathrm{O}_{2}^{-}\left(\mathrm{k}=2 \times 10^{9} \mathrm{~L} \mathrm{~mol}^{-1} \mathrm{~s}^{-1}\right)$ into $\mathrm{O}_{2}$ and $\mathrm{H}_{2} \mathrm{O}_{2}$ (16), as well as catalase (1-5 $\left.\times 10^{-6} \mathrm{~mol} / \mathrm{liter}\right)$, an enzyme that converts $\mathrm{H}_{2} \mathrm{O}_{2}$ into water and $\mathrm{O}_{2}$ at a relatively moderate rate $\left(\mathrm{k}=10^{7} \mathrm{~L} \mathrm{~mol}^{-1} \mathrm{~s}^{-1}\right.$; reference 16$)$. We hypothesized that a dysfunctional cNOS may trigger oxygen-derived free radical production in prehypertensive SHR (Fig. 1). We tested this hypothesis by examining the mediator(s) of endotheliumdependent relaxations and by directly measuring the $\mathrm{NO}, \mathrm{O}_{2}{ }^{-}$, and $\mathrm{H}_{2} \mathrm{O}_{2}$ production from the aortic endothelium in prehypertensive SHR and normotensive Wistar-Kyoto (WKY) rats.

1. Abbreviations used in this paper: cNOS, constitutive nitric oxide synthase; HOONO, peroxynitrous acid; HPLC, high performance liquid chromatography; $\mathrm{H}_{4} \mathrm{~B}$, (6R)-5,6,7,8-tetrahydrobiopterin; NADPH, nicotinamide adenine dinucleotide phosphate; NO, nitric oxide; L-NAME, $N^{\mathrm{G}}$-nitro-L-arginine methyl ester; L-NMMA, $N^{\mathrm{G}}$-monomethyl-L-arginine; $\mathrm{O}_{2}{ }^{-}$, superoxide; SHR, spontaneously hypertensive rats; SOD, superoxide dismutase; SSCE, silver/silver chloride reference electrode; WKY, Wistar-Kyoto. 
a

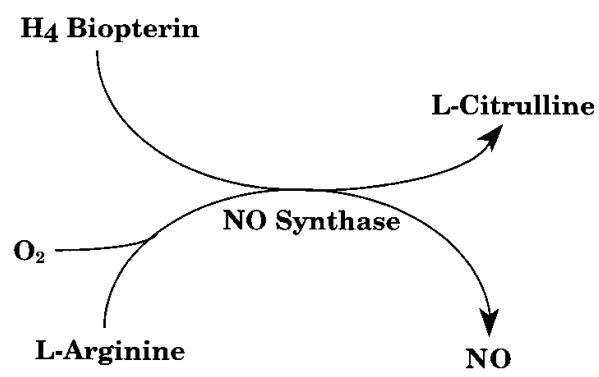

b

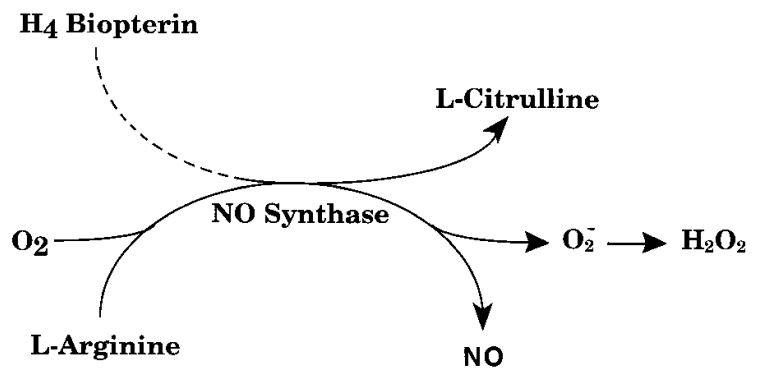

Figure 1. (a) Schematic representation of nitric oxide synthase (NO Synthase) reaction leading to L-citrulline and nitric oxide $(\mathrm{NO})$ from L-arginine and oxygen $\left(\mathrm{O}_{2}\right)$. (b) The activation of NO synthase at suboptimal levels (dashed line) of (6R)-5,6,7,8-tetrahydrobiopterin ( $\mathrm{H}_{4}$ Biopterin) generates superoxide anion $\left(\mathrm{O}_{2}{ }^{-}\right)$followed by the production of hydrogen peroxide $\left(\mathrm{H}_{2} \mathrm{O}_{2}\right)$ and/or peroxynitrite $\left(\mathrm{ONOO}^{-}\right)$ from the rapid reaction of $\mathrm{O}_{2}{ }^{-}$and $\mathrm{NO}$.

\section{Methods}

Animals. The experiments were performed on aortas of male SHR and WKY rats (4-wk-old; IFFA CREDO, L'Arbresle, France). All procedures were in accordance with institutional guidelines. Blood pressure was measured in the left femoral artery with a Letica PRI 256/2 equipment (Letica S/A Instruments, Hospitalet, Spain). Mean blood pressure of SHR did not differ from that of age-matched WKY rats $(69 \pm 8$ and $68 \pm 5 \mathrm{mmHg} ; n=6$ for SHR and WKY rats, respectively). Animals were anesthetized with thiopental $(50 \mathrm{mg} / \mathrm{kg} \mathrm{IP}$; Abbot Laboratories Diagnostic Division, Chicago, IL). The aorta was excised and immediately placed into cold $\left(4^{\circ} \mathrm{C}\right)$ control solutions. Under a dissection microscope (Wild M3C; Wild AG, Heerbrugg, Switzerland) the isolated aorta was cleaned of adherent connective tissue. For measurements of $\mathrm{NO}, \mathrm{O}_{2}^{-}, \mathrm{H}_{2} \mathrm{O}_{2}$ concentrations and organ chamber experiments, the preparations were immersed in HBSS and modified Krebs-Ringer bicarbonate solution, respectively. For measurements of $\mathrm{H}_{4} \mathrm{~B}$ levels and determination of NOS activity, the aortas were frozen in liquid nitrogen and stored at $-70^{\circ} \mathrm{C}$ until assay was performed.

Organ-chamber experiments. Aortas were cut into rings (3-4 mm long). In certain rings, the endothelium was mechanically removed. To inhibit cyclooxygenase, all experiments were performed in the presence of indomethacin $\left(10^{-5} \mathrm{~mol} / \mathrm{liter}\right)$. Each ring was connected to an isometric force transducer (SCAIME, Paris, France), suspended in an organ chamber filled with $25 \mathrm{ml}$ of modified Krebs-Ringer bicarbonate solution of the following composition (mmol/liter): $\mathrm{NaCl}$ 118.6, $\mathrm{KCl} 4.7, \mathrm{CaCl}_{2} 2.5, \mathrm{KH}_{2} \mathrm{PO}_{4} 1.2, \mathrm{MgSO}_{4} 1.2, \mathrm{NaHCO}_{3} 25.1$, calcium EDTA 0.026, glucose $10.1\left(37^{\circ} \mathrm{C} ; \mathrm{pH} 7.4\right)$, and bubbled with $95 \% \mathrm{O}_{2}-5 \% \mathrm{CO}_{2}$. Isometric tension was recorded continuously. Af- ter a 30-min equilibration period, rings were gradually stretched to the optimal point of their length-tension curve $(2.5 \pm 0.2 \mathrm{~g})$ as determined by the contraction to $\mathrm{KCl}(100 \mathrm{mmol} / \mathrm{liter})$. The functional integrity of the endothelium was tested by the presence of relaxations to acetylcholine $\left(10^{-6} \mathrm{~mol} /\right.$ liter $)$. Concentration-response curves were obtained in a cumulative fashion. Several rings cut from the same artery were studied in parallel; only one concentration-response curve was made per preparation. In quiescent preparations, indomethacin, $N^{\mathrm{G}}$-nitro-L-arginine methyl ester (L-NAME), catalase, and SOD did not affect resting tension. Responses to calcium ionophore A23187 were obtained during submaximal contraction to norepinephrine ( $3 \times 10^{-7} \mathrm{~mol} /$ liter). Incubation time was $30 \mathrm{~min}$ for indomethacin, 15 min for L-NAME, and 5 min for CAT and SOD. Relaxations were expressed as a percentage of maximal relaxations induced by papaverine $\left(3 \times 10^{-4} \mathrm{~mol} /\right.$ liter $)$.

Measurement of nitric oxide. NO was measured using a porphyrinic microsensor as described previously $(17,18)$. The porphyrinic microsensor has a response time of $0.1 \mathrm{~ms}$ at micromolar NO concentrations and $10 \mathrm{~ms}$ at the detection limit of $10^{-9} \mathrm{~mol} / \mathrm{liter}$.

Briefly, the NO microsensor was produced from a single carbon fiber $(6 \mu \mathrm{m}$ diameter, $12 \mathrm{ohm} \mathrm{cm}$; Amoco Performance Products, Greenville, SC). The tip of the carbon fiber was made more sensitive to potential interferents by deposition of a highly conductive polymeric porphyrin from a solution of $2.5 \times 10^{-4} \mathrm{~mol} /$ liter nickel (II) tetrakis (3-methoxy-4-hydroxyphenyl) porphyrin subsequently covered with Nafion ${ }^{\circledR}$. Linear calibration curves were constructed for each sensor (19). The porphyrinic NO sensor was routinely tested for possible interferences from all reagents and known secretable and readily oxidizable mammalian biochemicals at concentrations 10 times higher than the concentrations used in this study.

Amperometry was used for fast (resolution time $0.1-1 \mathrm{~ms}$ ) and continuous measurement of the changes of NO concentration. A three-electrode system was used for these measurements. It consisted of a porphyrinic microsensor working electrode, a platinum counter electrode (diameter $0.5 \mathrm{~mm}$ ), and a silver/silver chloride reference electrode (SSCE). Current was monitored using a Princeton Applied Research, PAR model 273 voltametric analyzer interfaced with an IBM 80486 computer with data acquisition and control software. Current-time curves (amperograms) were obtained at a constant potential $(0.66 \mathrm{~V})$, the peak potential for the oxidation of NO versus SSCE.

The sensor was lowered with a computer controlled micromanipulator until it reached the endothelial surface as described $(17,18)$. Immediately before NO measurement, an isolated open vascular ring was placed in an organ chamber with fresh, phenol red free HBSS, and the active tip of the microsensor was placed on the endothelium of the vascular ring, and a platinum counter electrode and a SSCE were placed on adjacent tissue. Then enough calcium ionophore A23187 was injected into the organ chamber to reach $8 \times 10^{-6} \mathrm{~mol} / \mathrm{li}$ ter. The experiment was then repeated in the presence of SOD or membrane permeable PEG-SOD $(100 \mathrm{U} / \mathrm{ml}$; from bovine erythrocytes coupled to methoxy-polyethylene glycol); after incubation for $60 \mathrm{~min}$ with $\mathrm{H}_{4} \mathrm{~B}\left(10^{-4} \mathrm{~mol} / \mathrm{liter}\right)$, in the presence or in the absence of SOD, and after incubation with $N^{\mathrm{G}}$-monomethyl-L-arginine (L-NMMA) or L-NAME $\left(2 \times 10^{-5} \mathrm{~mol} /\right.$ liter $)$ in HBSS.

Measurement of hydrogen peroxide. $\mathrm{A}_{2} \mathrm{H}_{2}$ electrode was prepared as described (20). Briefly, horseradish peroxidase (Sigma Chemical Co., St. Louis, MO) was immobilized in epoxy hydrogel on a current collector (carbon fiber Amoco; diameter, $7 \mu \mathrm{m}$ ). The redox hydrogel was made of a poly (4 - vinyl pyridine) backbone complexed by osmium redox polyamine as described (21). Electrode coating was prepared by mixing the enzyme, $(30 \% \mathrm{wt} / \mathrm{wt})$ polymer and the cross-linker solution (1:2 molar ratio). The amperometric measurements were performed at $-0.2 \mathrm{~V}$ (versus SSCE) using the same set up described above for NO measurements. The detection limit for $\mathrm{H}_{2} \mathrm{O}_{2}$ was $10^{-8} \mathrm{~mol} /$ liter.

Measurement of superoxide by lucigenin-mediated chemiluminescence. The superoxide $\left(\mathrm{O}_{2}{ }^{-}\right)$concentration in aortic tissue was determined by a chemiluminescence method (22). $\mathrm{O}_{2}{ }^{-}$produced chemilu- 
minescence of lucigenin (bis- $N$-methylacridinium nitrate; Aldrich Chemical Co., Milwaukee, WI) was detected with a scintillation counter (Beckman 6000 LS, with a single photon monitor; Beckman Instruments, Inc., Fullerton, CA). Each $(0.8-1.5 \mathrm{mg})$ tissue sample was placed in $2 \mathrm{ml}$ of HBSS adjusted to $\mathrm{pH} 7.4$, then enough lucigenin was added to make its concentration $2.5 \times 10^{-4} \mathrm{~mol} / \mathrm{liter}$. Basal $\mathrm{O}_{2}$ concentration produced by the tissue was measured after a 2-min incubation in HBSS. The total of the $\mathrm{O}_{2}{ }^{-}$produced was measured in a similar manner: the 2-min incubation period was followed by injection of $10 \mu \mathrm{l}$ of $1.2 \times 10^{-3} \mathrm{~mol} /$ liter A23187. Photons were counted during the first $20 \mathrm{~s}$ after addition of A23187 and were calibrated as $\mathrm{O}_{2}{ }^{-}$concentration by constructing standard curves based on photons emitted by $\mathrm{O}_{2}{ }^{-}$stoichiometrically generated by reaction of xanthine and xanthine oxidase. An absolute colorimetric method of standardization based on the integration of electrical charge transferred during the reaction of $\mathrm{O}_{2}{ }^{-}$with an electrode was used to correlate photon counts measured by chemiluminescence to the actual concentrations of $\mathrm{O}_{2}^{-}$(19).

Preparation of tissue extracts. Tissue was homogenized in a glass pistill in distilled water containing $0.1 \mathrm{mg} / \mathrm{ml}$ pefabloc SC (Merck, Darmstadt, Germany) and $5 \times 10^{-3} \mathrm{~mol} /$ liter dithioerythrol, then centrifuged at $4^{\circ} \mathrm{C}$ and $13.000 \mathrm{~g}$ for $15 \mathrm{~min}$. In some experiments, the pellet of the first centrifugation was resuspended in the same solution containing $20 \mathrm{mmol} /$ liter 3-([3-cholamidopropyl]-dimethylammonio)1-propanesulfonate (CHAPS; Sigma Chemical Co.) and centrifuged again at the same conditions.

Determination of tetrahydrobiopterin concentrations by high performance liquid chromatography (HPLC). Determination of $\mathrm{H}_{4} \mathrm{~B}$ concentrations by HPLC was performed as described (23). Briefly, for the oxidation of the reduced nonfluorescent di- and tetrahydrobiopterin to a fluorescent biopterin, $100 \mu \mathrm{l}$ of tissue extract was mixed with $10 \mu \mathrm{l} 1 \mathrm{~N} \mathrm{HCl}$ and $10 \mu l 0.1 \mathrm{M} \mathrm{I}_{2}$ (dissolved in $0.25 \mathrm{M} \mathrm{KI}$ ) and incubated for $60 \mathrm{~min}$ in the dark. After centrifugation $(2 \mathrm{~min}, 13.000 \mathrm{~g})$, $10 \mu \mathrm{l} 0.1 \mathrm{M}$ ascorbic acid was added to the supernatant. $30 \mu \mathrm{l}$ was then injected onto a $250 \mathrm{~mm}$ long, $4 \mathrm{~mm}$ inner diameter RP-18 column (Lichrospher, $5 \mu \mathrm{m}$ particle size; Merck), isocritically eluted with $15 \mathrm{mmol} /$ liter potassium phosphate buffer, $\mathrm{pH} 6.0$, at a flow rate of $0.8 \mu \mathrm{l} / \mathrm{min} . \mathrm{H}_{4} \mathrm{~B}$ was detected by fluorescence at $350 \mathrm{~nm}$ (excitation) and $440 \mathrm{~nm}$ (emission).

Determination of cNOS activity. Determination of cNOS activity was carried out as described (24). Briefly, tissue extracts were freed from low molecular weight compounds with NAP-5 columns (Pharmacia Fine Chemicals, Uppsala, Sweden). Protein fraction was eluted with $40 \mathrm{mmol} /$ liter Tris-HCl buffer, containing $0.1 \mathrm{mg} / \mathrm{ml}$ Pefabloc SC. Standard reaction mixtures contained $100 \mathrm{mmol} /$ liter L-arginine, $25 \mu \mathrm{mol} /$ liter FAD, $25 \mu \mathrm{mol} /$ liter FMN, 2 mmol/liter NADPH, 0.15 $\mathrm{mmol} /$ liter EGTA, $0.9 \mathrm{mmol} /$ liter EDTA, $1.78 \mathrm{mmol} / \mathrm{liter} \mathrm{MgCl}_{2}, 0.27$ $\mathrm{mmol} /$ liter $\mathrm{CaCl}_{2}, 5 \mu \mathrm{mol} /$ liter (6R)-5,6,7,8-tetrahydrobiopterin and $60,000-80,000 \mathrm{cpm}$ of purified L-[2,3,4,5 $3 \mathrm{H}]$ arginine (Amersham Life Sciences, Arlington Heights, IL), and $100 \mu \mathrm{l}$ of tissue extract in a final volume of $200 \mu \mathrm{l}$. After incubation at $37^{\circ} \mathrm{C}$ for $30 \mathrm{~min}$, the reaction was stopped by addition of $800 \mu 1200 \mathrm{mmol} /$ liter sodium acetate, $\mathrm{pH} 5.0$, containing $200 \mu \mathrm{mol} /$ liter EDTA and $1 \mathrm{mmol} /$ liter L-citrulline. $\left[{ }^{3} \mathrm{H}\right]$ Citrulline was quantified after separation from $[3 \mathrm{H}]$ arginine by cation exchange on Dowex 50W.

Drugs. Acetylcholine chloride, calcium ionophore A23187, catalase, indomethacin, L-NAME, L-NMMA, norepinephrine, papaverine hydrochloride, sodium nitroprusside, superoxide dismutase (from bovine erythrocytes, 4,400 U/mg protein) and chemical components of the physiological salt solutions (HBSS and Krebs-Ringer) were obtained from Sigma Chemical Co. (6R)-5,6,7,8-tetrahydro-L-biopterin dihydrochloride was obtained from Schircks Laboratories (Jona, Switzerland). Stock solutions of the drugs were freshly prepared every day. Drugs were dissolved in distilled water such that volumes of less than $0.2 \mathrm{ml}$ were added to the organ chambers. A stock solution of $10^{-5} \mathrm{~mol} / \mathrm{liter}$ indomethacin was prepared in equal molar concentrations of $\mathrm{Na}_{2} \mathrm{CO}_{3}$. A stock solution of $1.2 \times 10^{-3} \mathrm{~mol} / \mathrm{liter}$ of A23187 was prepared in dimethyl sulfoxide. All concentrations are expressed as final molar (mol/liter) concentration in the bath solutions.

Statistical analysis. All experiments were performed in parallel on preparations from SHR and WKY rats. In each set of experiments, $n$ equals the number of experiments. Results are expressed as mean \pm SEM. Statistical evaluation of the data was performed by using Student's $t$ test for unpaired observations. A value of $P<0.05$ was considered statistically significant.

\section{Results}

Nitric oxide release. After stimulation with calcium ionophore A23187 ( $8 \times 10^{-6} \mathrm{~mol} /$ liter $)$, NO concentration bursts from the aortas of 4-wk-old SHR and WKY rats, were measured using a porphyrinic sensor placed near the endothelial surface $(5 \pm 2$ $\mu \mathrm{m})$. Amperometric curves showing the change of NO concentration with time, recorded in the absence and presence of SOD $(100 \mathrm{U} / \mathrm{ml})$ or $\mathrm{H}_{4} \mathrm{~B}\left(10^{-4} \mathrm{~mol} /\right.$ liter $)$, are depicted in Fig. 2. After the addition of $\mathrm{A} 23187$, a rapid increase of NO concentration was observed; peak NO concentrations were higher for WKY rats than for SHR $(200 \pm 5$ and $120 \pm 5 \mathrm{nmol} /$ liter, respectively, $n=7, P<0.005)$.

Since SOD catalyzes $\mathrm{O}_{2}{ }^{-}$dismutation, we used the difference in NO concentration recorded with and without SOD as

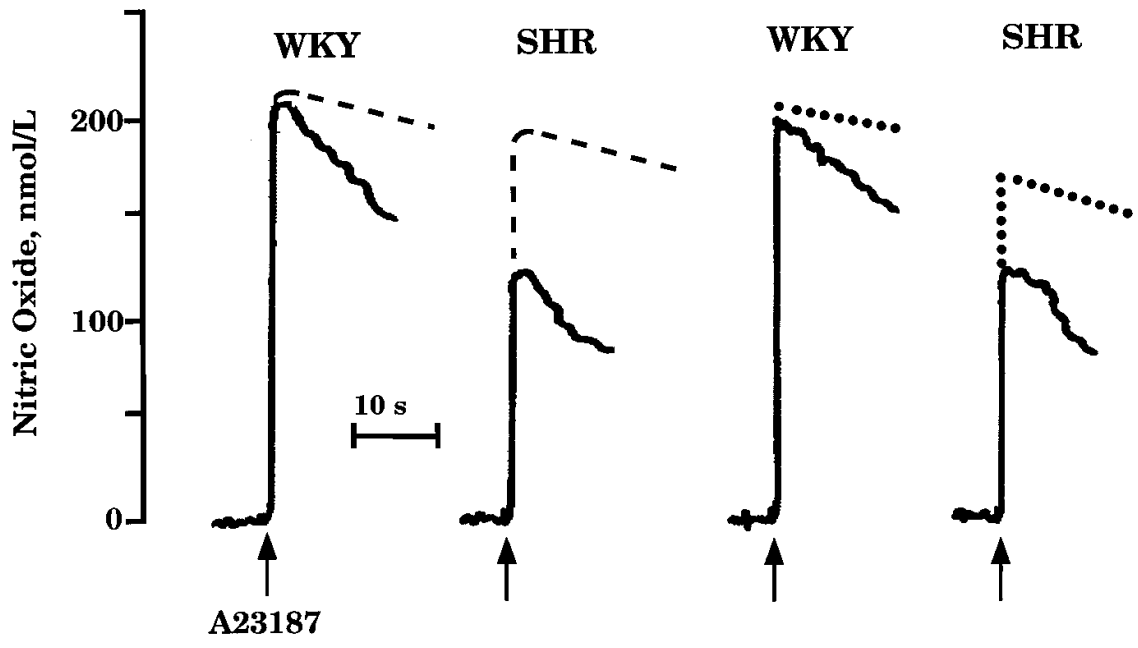

Figure 2. Typical amperograms showing changes of nitric oxide concentrations near the surface of endothelial cells from the aorta of 4-wk-old Wistar-Kyoto (WKY) and spontaneously hypertensive rats $(S H R)$. NO release was stimulated with calcium ionophore A23187 $\left(8 \times 10^{-6} \mathrm{~mol} /\right.$ liter, solid line $)$. Amperograms obtained during stimulation with A23187 in the presence of SOD $(100 \mathrm{U} / \mathrm{ml}$, dashed line $)$, or after incubation with $\mathrm{H}_{4} \mathrm{~B}\left(10^{-4} \mathrm{~mol} / \mathrm{liter}\right.$, dotted line) are shown. 
an indirect approach to estimate production of $\mathrm{O}_{2}^{-}$at the time of NO release. In the presence of SOD a small $8 \%$ increase of peak NO concentration was observed for WKY rats and a significant $54 \%$ increase for SHR (216 \pm 6 and $185 \pm 5 \mathrm{nmol} / \mathrm{liter}$, respectively). A small difference in NO signal (10 and 62\% increase of peak NO concentration in WKY and SHR, respectively) was observed with membrane permeable PEG-SOD (data not shown). Similar increases in peak NO production were observed after incubation of aortas with $\mathrm{H}_{4} \mathrm{~B} ; 5 \%$ for WKY and about $50 \%$ for SHR $(210 \pm 5$ and $178 \mathrm{nmol} / \mathrm{liter}$, respectively, $n=7, P<0.005)$. After incubation of aortas with $\mathrm{H}_{4} \mathrm{~B}$ we did not detect a further increase of $\mathrm{NO}$ signal in the presence of either SOD or PEG-SOD (data not shown).

Superoxide anion and hydrogen peroxide release. The difference in peak NO concentrations in the presence and absence of SOD suggests that A23187 not only stimulates NO release, but also causes the simultaneous release of $\mathrm{O}_{2}^{-}$. This possibility was confirmed by the use of a chemiluminescence method to make direct in vitro measurement of $\mathrm{O}_{2}{ }^{-}$in aortic tissue. Also, one of the $\mathrm{O}_{2}{ }^{-}$dismutase products, $\mathrm{H}_{2} \mathrm{O}_{2}$, was measured with a $\mathrm{H}_{2} \mathrm{O}_{2}$ selective electrode.

$\mathrm{O}_{2}{ }^{-}$and $\mathrm{H}_{2} \mathrm{O}_{2}$ concentrations were measured in the aorta of SHR and WKY rats before and after stimulation with A23187 (Fig. 3). In WKY, the concentration of $\mathrm{O}_{2}{ }^{-}$increased from $10 \pm 2$ to $16 \pm 3 \mathrm{nmol} / \mathrm{mg}$ tissue, respectively (Fig. 3, top); the corresponding increase in $\mathrm{H}_{2} \mathrm{O}_{2}$ production was insignificant. After incubation with SOD or $\mathrm{H}_{4} \mathrm{~B}, \mathrm{O}_{2}{ }^{-}$production stimulated by A23187 decreased to its basal level. Furthermore, it is interesting to note that in WKY, after SOD treatment $\mathrm{H}_{2} \mathrm{O}_{2}$ production increased to $10 \pm 2 \mathrm{nmol} /$ liter. By contrast, in SHR the basal production of $\mathrm{O}_{2}^{-}$and $\mathrm{H}_{2} \mathrm{O}_{2}$ was higher than that observed in WKY rats (Fig. 3, bottom); the $\mathrm{O}_{2}{ }^{-}$concentration increased significantly after stimulation with A23187 (18 \pm 3 and $65 \pm 4 \mathrm{nmol} / \mathrm{mg}$ tissue, respectively). In the presence of SOD the $\mathrm{O}_{2}{ }^{-}$concentration decreased to basal level and $\mathrm{H}_{2} \mathrm{O}_{2}$ increased three times in comparison to the control $(59 \pm 4 \mathrm{nmol} /$ liter). This clearly indicates that $\mathrm{O}_{2}{ }^{-}$is entirely dismutated by $\mathrm{SOD}$ in this system. The presence of membrane permeable PEG-SOD caused additional 15\% decrease/increase in $\mathrm{O}_{2}{ }^{-}$ and $\mathrm{H}_{2} \mathrm{O}_{2}$ production, respectively, as compared with SOD treatment (data not shown).

As a negative control, $2 \times 10^{-5} \mathrm{~mol} / \mathrm{liter}$ doses of known inhibitors of cNOS, after $10 \mathrm{~min}$ incubation, were found to reduce $\mathrm{O}_{2}^{-}$from both SHR and WKY rats after stimulation with

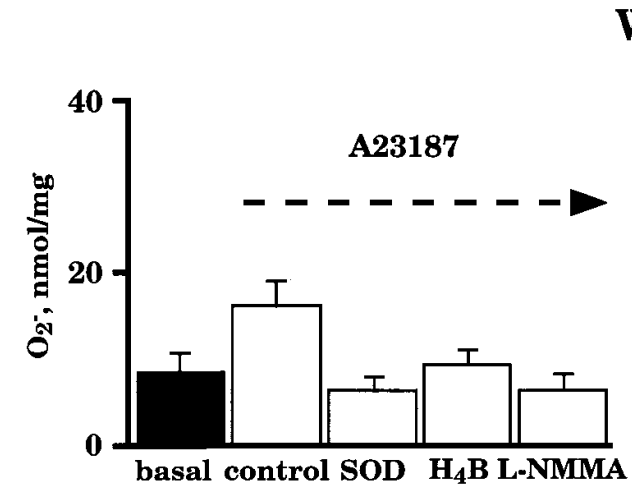

WKY

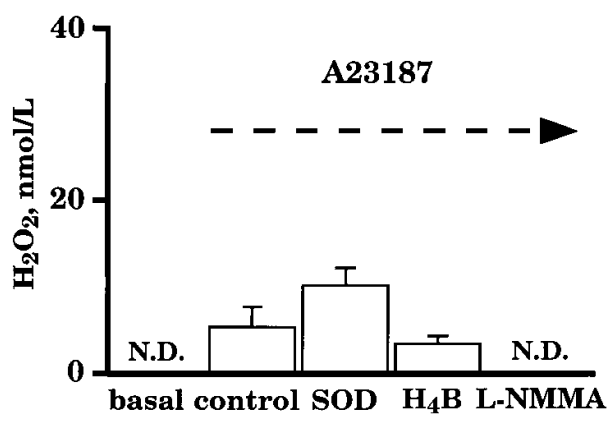

\section{SHR}

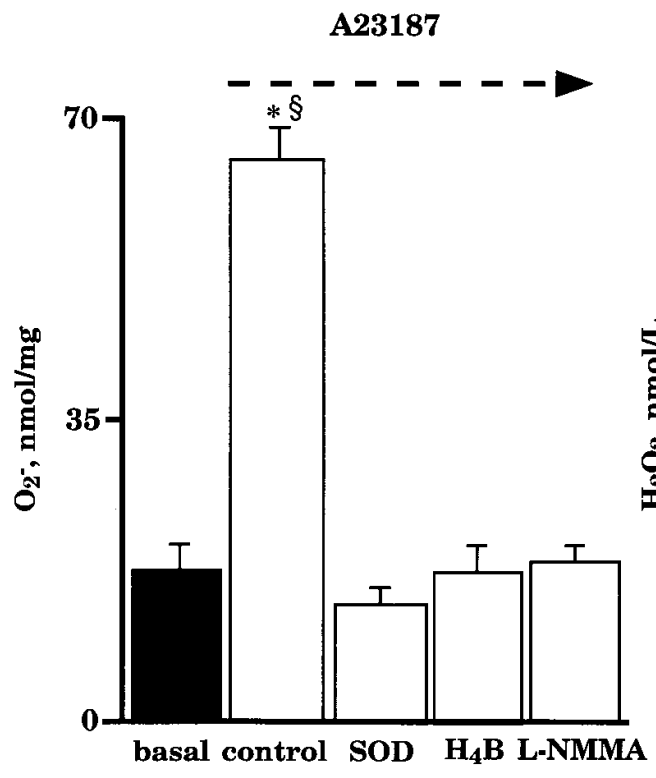

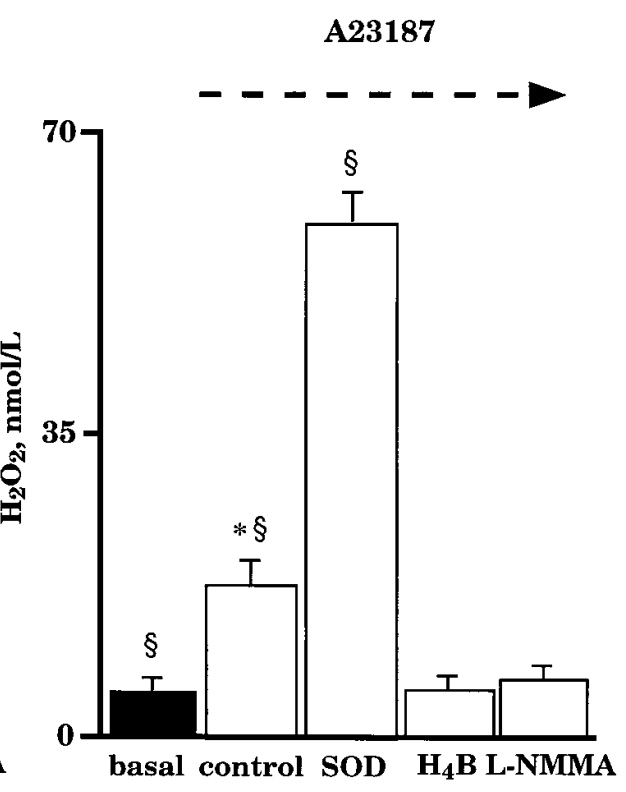

Figure 3. Bar graphs showing the concentration of superoxide $\left(\mathrm{O}_{2}^{-}\right)$ and hydrogen peroxide $\left(\mathrm{H}_{2} \mathrm{O}_{2}\right)$ in aortic tissue from 4-wk-old WistarKyoto rats $(W K Y$, top $)$ and spontaneously hypertensive rats (SHR, bottom). Basal concentrations were measured without stimulation of cNOS by calcium ionophore $\mathrm{A} 23187$ $\left(8 \times 10^{-6} \mathrm{~mol} / \mathrm{liter}\right)$. Total concentrations (control) were measured after stimulation with A23187; also, in the presence of SOD $(100 \mathrm{U} / \mathrm{ml})$, or after incubation with (6R)-5,6,7,8tetrahydrobiopterin $\left(H_{4} B, 10^{-4} \mathrm{~mol} /\right.$ liter), and in the presence of $N^{\mathrm{G}}$ monomethyl-L-arginine (L-NMMA, $\left.2 \times 10^{-5} \mathrm{~mol} / \mathrm{liter}\right)$. Values are means $\pm \operatorname{SEM}(n=7)$. $* P<.05$ compared with corresponding basal values; ${ }^{\S} P<.05$ compared with values in WKY rats. 

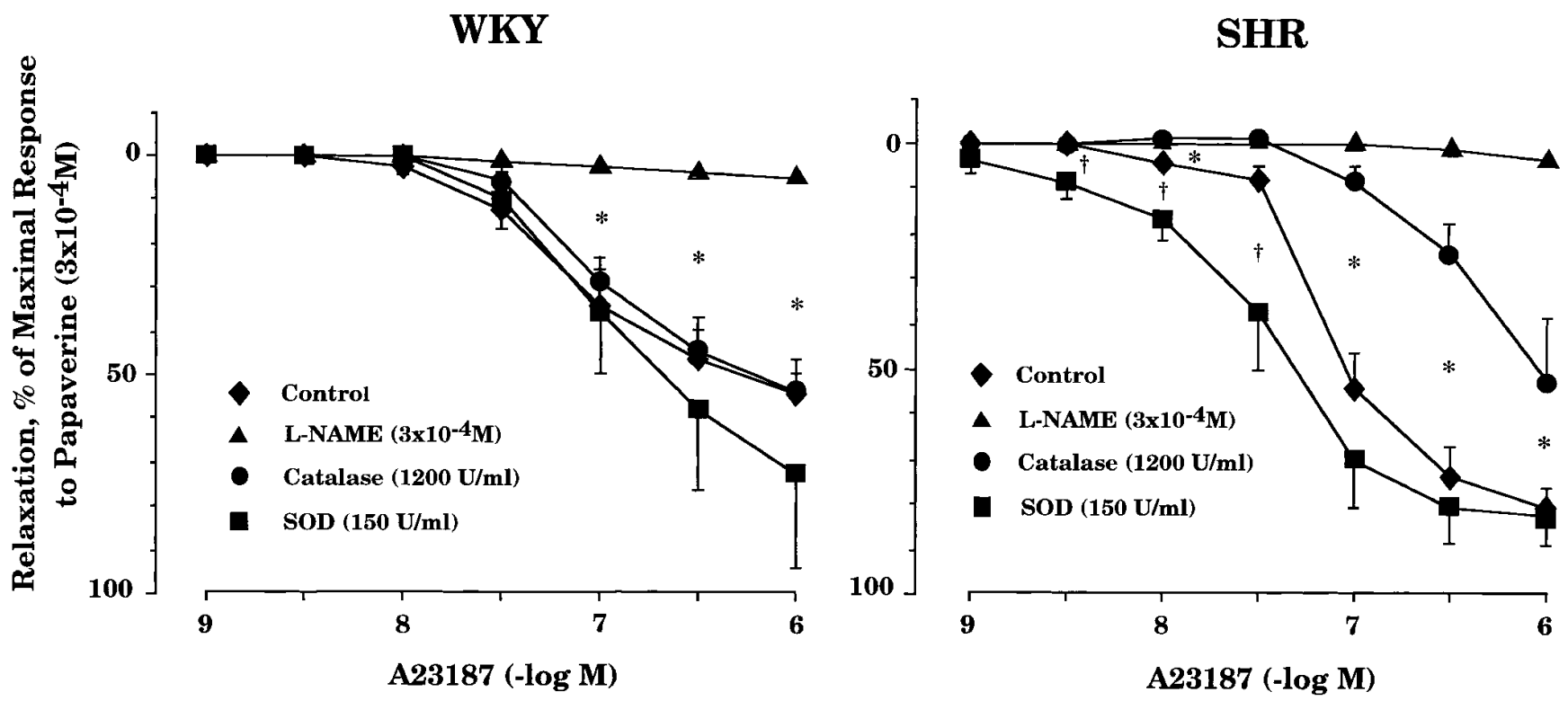

Figure 4. Line graphs showing concentration-response curves to calcium ionophore A23187 in aortas with endothelium of Wistar-Kyoto (WKY, left $)$ and spontaneously hypertensive rats $\left(\mathrm{SHR}\right.$, right). Relaxations were obtained during contractions to norepinephrine $\left(3 \times 10^{-7} \mathrm{~mol} / \mathrm{liter}\right)$ in control rings and rings treated with L-NAME, catalase, or SOD. Data are means \pm SEM $(n=5-6$ for each group). *Significant difference between control and L-NAME-treated rings or control and catalase-treated rings $(P<.05)$. "Significant difference between control and SODtreated rings $(P<0.05)$.

A23187. L-NAME and L-NMMA inhibited A23187-induced production of $\mathrm{O}_{2}^{-}$by $25 \%$ (data not shown) and $70 \%$ (Fig. 3). The relative inhibition of $\mathrm{O}_{2}^{-}$production by L-NAME and L-NMMA was similar to the inhibitory effect of the two L-arginine analogs on A23187-induced NO release $(28 \%$ and $68 \%$, respectively).

Endothelium-dependent relaxations to A23187. During contractions to norepinephrine $\left(3 \times 10^{-7} \mathrm{~mol} / \mathrm{liter}\right)$ calcium ionophore A23187 $\left(10^{-9}-10^{-6} \mathrm{~mol} / \mathrm{liter}\right)$ caused endotheliumdependent relaxations both in WKY and SHR (Fig. 4). A23187-induced relaxations were greater in SHR. Inhibition of cNOS with L-NAME $\left(3 \times 10^{-4} \mathrm{~mol} /\right.$ liter $)$ abolished relaxations to A23187 in both strains (Fig. 4). Accordingly, A23187induced relaxations were abolished by a different cNOS inhibitor diphenylene iodonium $\left(10^{-5} \mathrm{~mol} / \mathrm{liter}\right.$; data not shown). Only in SHR, the relaxations were significantly inhibited by catalase $(1,200 \mathrm{U} / \mathrm{ml})$ and enhanced by SOD $(150 \mathrm{U} / \mathrm{ml}$; Fig. $4)$. By contrast, SOD plus catalase did not exert any effect on the response to A23187 (Table I). Also, inhibition of xanthine oxidase with oxypurinol $\left(10^{-5} \mathrm{~mol} / \mathrm{liter}\right)$ did not affect these relaxations (Table I). Furthermore, the effects of catalase or SOD on A23187-induced relaxations were abolished in the presence of the natural cofactor for $\mathrm{cNOS}, \mathrm{H}_{4} \mathrm{~B}\left(10^{-4} \mathrm{~mol} / \mathrm{liter}\right.$; Fig. 5), but not affected by exogenous L-arginine $\left(10^{-3} \mathrm{~mol} / \mathrm{li}-\right.$ ter; data not shown). The absence or the presence of cyclooxygenase inhibitor indomethacin $\left(10^{-5} \mathrm{~mol} / \mathrm{liter}\right)$ did not affect the response to A23187 in SHR aortas (-Log EC 50 : 7.2 \pm 0.04 and $7.2 \pm 0.06 ; n=8$; with and without indomethacin, respectively). Similar findings were obtained with acetylcholine $\left(10^{-9}-10^{-4} \mathrm{~mol} /\right.$ liter; data not shown $)$.

Endothelium-independent relaxations to sodium nitroprusside. During contractions induced with norepinephrine, the NO donor sodium nitroprusside $\left(10^{-10}-10^{-5} \mathrm{~mol} / \mathrm{liter}\right)$ caused concentration-dependent relaxations in SHR aorta without endothelium. Catalase, SOD, and L-NAME did not affect the relaxations to sodium nitroprusside (Table I).

Levels of tetrahydrobiopterin and measurements of cNOS activity. The levels of $\mathrm{H}_{4} \mathrm{~B}$, assessed by HPLC, were not significantly different in SHR and in WKY aortas $(6.4 \pm 0.5$ and $7.5 \pm 0.7 \mathrm{pmol} / \mathrm{mg}$, respectively; $n=15)$. By contrast, cNOS activity was significantly higher in WKY than in SHR aortas after $\mathrm{H}_{4} \mathrm{~B}$ supplementation (Fig. 6).

Table I. EC $C_{50}$ and Maximal Relaxations in SHR Aortas With (A) and Without Endothelium (B) in Response to A23187 and Sodium Nitroprusside, Respectively. Effect of SOD plus Catalase, Oxypurinol, SOD, and Catalase alone, $N^{G}$-nitro-L-arginine methyl ester

\begin{tabular}{lccc}
\hline & $-\log \mathrm{EC}_{50}$ & Maximal relaxation $(\%)$ & $n$ \\
\hline A $\quad$ & & & \\
$\quad$ Control & $7.2 \pm 0.1$ & $74 \pm 9$ & 4 \\
$\quad$ SOD $(150 \mathrm{U} / \mathrm{ml})+$ & & & \\
$\quad$ Catalase $(1200 \mathrm{U} / \mathrm{ml})$ & $7.3 \pm 0.1$ & $79 \pm 5$ & 4 \\
$\quad$ Oxypurinol $\left(10^{-5} \mathrm{M}\right)$ & $7.0 \pm 0.1$ & $71 \pm 9$ & 6 \\
B & & & \\
Control & $7.8 \pm 0.1$ & 100 & 4 \\
SOD $(150 \mathrm{U} / \mathrm{ml})$ & $8.0 \pm 0.1$ & 100 & 4 \\
Catalase $(1200 \mathrm{U} / \mathrm{ml})$ & $7.9 \pm 0.1$ & 100 & 4 \\
L-NAME $\left(3 \times 10^{-4} \mathrm{M}\right)$ & $7.8 \pm 0.1$ & 100 & 4 \\
\end{tabular}

$\mathrm{EC}_{50}$ indicates half-maximal effective concentration; $n$, number of rats. Values are mean \pm SEM. Relaxations are expressed as percent of maximal relaxation to papaverine $\left(3 \times 10^{-4} \mathrm{~mol} / \mathrm{l}\right)$. Relaxations were obtained during contractions to norepinephrine $\left(3 \times 10^{-7} \mathrm{~mol} / \mathrm{l}\right)$. 


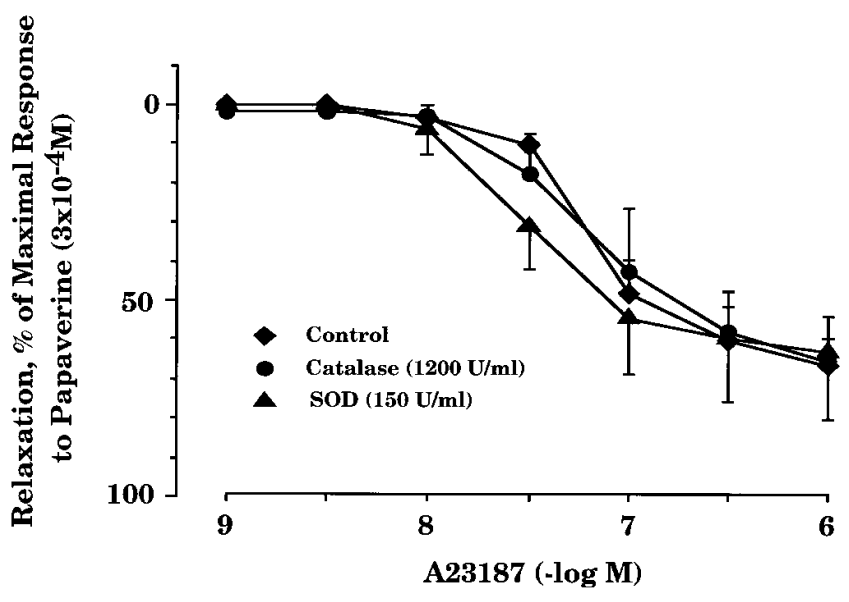

Figure 5. Line graph showing concentration-response curves to calcium ionophore A23187 in aortas with endothelium of spontaneously hypertensive rats incubated in the presence of (6R)-5,6,7,8-tetrahydrobiopterin $\left(10^{-4} \mathrm{~mol} / \mathrm{liter}\right)$. Relaxations were obtained during contractions to norepinephrine $\left(3 \times 10^{-7} \mathrm{~mol} /\right.$ liter $)$ in control rings and rings treated with catalase or SOD. Data are means \pm SEM $(n=4$ for each group).

\section{Discussion}

This study demonstrates that cNOS-dependent generation of $\mathrm{O}_{2}{ }^{-}$occurs in prehypertensive SHR aorta. This conclusion is supported by several lines of evidence. First, the peak endothelial NO concentrations, after A23187 stimulation, were significantly smaller in the aortas of SHR than in WKY rats. Second, $\mathrm{H}_{4} \mathrm{~B}$ supplementation in SHR diminished the cNOSdependent generation of $\mathrm{O}_{2}{ }^{-}$and its dismutase product $\mathrm{H}_{2} \mathrm{O}_{2}$, while it increased the net NO production. Finally, only in SHR were the endothelium-dependent relaxation in response to A23187 significantly enhanced by SOD and inhibited by catalase.

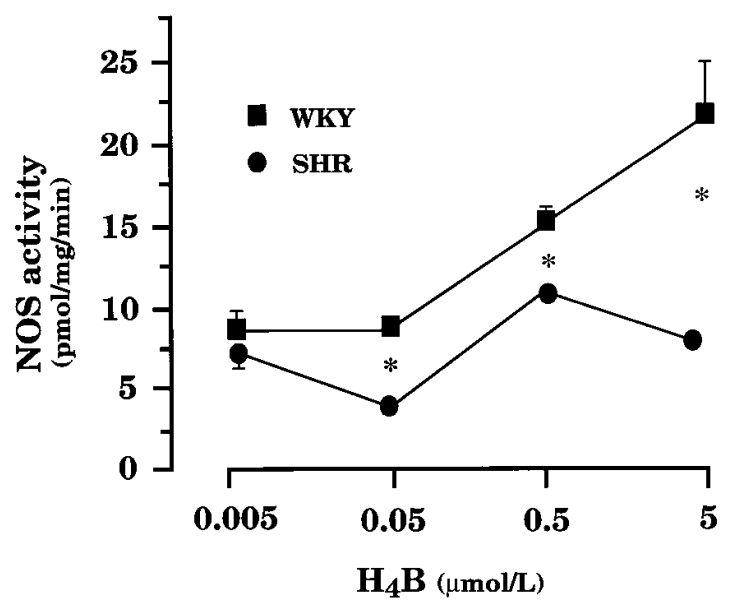

Figure 6. Line graph showing the effect of various doses of (6R)5,6,7,8-tetrahydrobiopterin (expressed as micromoles per liter) on constitutive nitric oxide synthase activity (expressed as picomoles of L-citrulline generated per milligram of aortic tissue per minute) in aortas with endothelium of Wistar-Kyoto $(W K Y)$ and spontaneously hypertensive rats $(S H R)$. Data are means $\pm \operatorname{SEM}(n=3)$. *Significant difference between WKY and SHR $(P<0.05)$.
There are many sources of $\mathrm{O}_{2}^{-}$in the endothelium including cyclooxygenase, xanthine oxidase, and NADH oxidoreductase $(15,25,26)$. However, it has also been demonstrated that isolated neuronal cNOS may produce $\mathrm{O}_{2}{ }^{-}$in $\mathrm{H}_{4} \mathrm{~B}$ or L-arginine starved and SOD-free environments (10). In this work, confirmation that cNOS rather than other sources produced most of the $\mathrm{O}_{2}{ }^{-}$in prehypertensive SHR came from experiments showing $\mathrm{O}_{2}^{-}$release after treatment with a $\mathrm{NO}$ agonist, as well as its inhibition after incubation with known cNOS inhibitors. The rapid accumulation of $\mathrm{O}_{2}{ }^{-}$concentration in the presence of $\mathrm{A} 23187$ suggests that production of $\mathrm{O}_{2}{ }^{-}$is calciumdependent like the production of NO by cNOS. Furthermore, as with $\mathrm{NO}$ production, $\mathrm{O}_{2}^{-}$production can be inhibited by L-arginine analogs, such as L-NMMA and L-NAME. We observed that the sum of the $\mathrm{O}_{2}^{-}$produced by all non-cNOS sources, without A23187 stimulation (basal release), accounts for only $25-30 \%$ of the total $\mathrm{O}_{2}^{-}$produced after stimulation by A23187. Therefore, it can be assumed that the remaining 70 $75 \%$ is associated with calcium-dependent cNOS. Interestingly, the release of this particular fraction of $\mathrm{O}_{2}{ }^{-}$was almost entirely inhibited by L-NMMA.

The organ chamber experiments in this study were performed in the presence of indomethacin to rule out the possibility that free radical production was initiated by activation of arachidonic acid metabolism via the cyclooxygenase pathway. Endothelium-dependent relaxations in response to A23187 were present in aortas of both SHR and WKY rats. L-NAME abolished these relaxations, demonstrating that the effect of A23187 is mediated by activation of cNOS. Further analysis revealed that catalase inhibited, and SOD enhanced, the endothelium-dependent relaxations to A23187 only in SHR aortas, suggesting that $\mathrm{H}_{2} \mathrm{O}_{2}$, a product of $\mathrm{O}_{2}^{-}$dismutation formed via cNOS, becomes a mediator of these relaxations. The lack of this SOD effect in the presence of catalase support this conclusion. Indeed, previous studies $(14,27,28)$ provided evidence that $\mathrm{H}_{2} \mathrm{O}_{2}$ is a potent vasodilator through direct activation of soluble guanylyl cyclase in smooth muscle cells and increase of cyclic GMP. Also, we ruled out the possibility that xanthine oxidase could be a source of reduced oxygen species. Oxypurinol a selective inhibitor of this enzyme did not exert any effect on A23187-induced relaxations. Targeting of other oxidative enzymes by pharmacological inhibitors may be difficult. Diphenylene iodonium, a selective inhibitor of NADPH oxidoreductase, also inhibits NOS (29, 30). Accordingly, A23187-induced relaxations were abolished by this agent. Its inhibitory effect on both enzymes may further confuse the issue of which and how much each source contributes to increase $\mathrm{O}_{2}{ }^{-}$generation. On the basis of the specificity of L-arginine analogs (L-NMMA, L-NAME) for NOS and the fact that reciprocal changes in $\mathrm{O}_{2}^{-}$release are observed, it is unlikely the increase of $\mathrm{O}_{2}{ }^{-}$is derived from non-NOS. However, we are aware that our data do not completely exclude such a possibility.

Furthermore, SOD, catalase, and L-NAME did not affect relaxations to a NO donor sodium nitroprusside in preparations without endothelium, which strongly suggests that $\mathrm{O}_{2}{ }^{-}$is not produced by smooth muscle cells in SHR aortas.

Interestingly, incubation of SHR aortas with supplementary $\mathrm{H}_{4} \mathrm{~B}$, abolished the effect of catalase and SOD on A23187induced relaxations. Furthermore, after treatment with elevated $\mathrm{H}_{4} \mathrm{~B}$ concentration, any significant difference in the concentrations of $\mathrm{NO}, \mathrm{O}_{2}{ }^{-}$and $\mathrm{H}_{2} \mathrm{O}_{2}$ between the two strains disap- 
peared. By contrast, L-arginine only slightly attenuated the inhibitory effect of catalase on the response to A23187. The effect of exogenous supplementation of $\mathrm{H}_{4} \mathrm{~B}$ is consistent with the concept of an altered $\mathrm{H}_{4} \mathrm{~B}$-cNOS interaction which may be related to an impaired synthesis (13) or decreased affinity of the enzyme for the cofactor (31). To more precisely characterize the mechanisms leading to such cNOS-catalyzed production of $\mathrm{O}_{2}{ }^{-}$, we measured the levels of $\mathrm{H}_{4} \mathrm{~B}$ in the vessel wall as well as the activity of NOS in response to exogenous $\mathrm{H}_{4} \mathrm{~B}$. Although $\mathrm{H}_{4} \mathrm{~B}$ concentrations were lower in SHR than in WKY aortas, the difference was not statistically significant. In contrast, cNOS activity (measured as picomol of L-citrulline produced per milligram of aortic tissue per minute) was significantly higher in WKY when compared with SHR aortas. These results would suggest that an increased requirement for $\mathrm{H}_{4} \mathrm{~B}$ may trigger an uncoupling of the oxidative and reductive domain of the enzyme resulting in dysfunctional cNOS activity in prehypertensive SHR. However, the possibility that $\mathrm{H}_{4} \mathrm{~B}$ has no allosteric effect on cNOS cannot be excluded based on our current data. It is possible that when the cNOS- $\mathrm{H}_{4} \mathrm{~B}$ interaction decreases below some critical level, no conformation changes occur between the two domains of the enzyme; cNOS simply starts reducing its other substrate $\mathrm{O}_{2}$ into $\mathrm{O}_{2}{ }^{-}$. Neither dynamic nor static model of cNOS- $\mathrm{H}_{4} \mathrm{~B}$ interaction can be proven without tertiary crystallographic structures of the enzyme in the presence and in the absence of $\mathrm{H}_{4} \mathrm{~B}$. Therefore, at this time, it is safe to assert, based on direct measurements of $\mathrm{O}_{2}{ }^{-}$by a chemiluminescence method, that $\mathrm{O}_{2}{ }^{-}$is produced in relatively high concentration in endothelium of prehypertensive SHR and this production is inversely related to NO accumulation.

Even though the total NO production in SHR (in the presence of SOD) is comparable with WKY, the concomitant increased production of $\mathrm{O}_{2}^{-}$may rapidly react with it $(\mathrm{k}=3.8 \times$ $10^{9} \mathrm{~L} \mathrm{~mol}^{-1} \mathrm{~s}^{-1}$ ) to produce the stable product peroxynitrite $\left(\mathrm{OONO}^{-} ; 32\right)$. This reaction is even faster than the one of $\mathrm{O}_{2}^{-}$ with SOD $\left(\mathrm{k}=2 \times 10^{9} \mathrm{~L} \mathrm{~mol}^{-1} \mathrm{~s}^{-1}\right)$ to form $\mathrm{H}_{2} \mathrm{O}_{2}$ and $\mathrm{O}_{2}$. Any $\mathrm{OONO}^{-}$produced when protonated $\left(\mathrm{pK}_{\mathrm{a}}=6.8\right)$ forms peroxynitrous acid (HOONO) which usually undergoes isomerization $\left(t_{1 / 2}<1 \mathrm{~s}\right)$ to form hydrogen cation and nitrate anion (33). However, if for any reason the HOONO concentration increases, as maximal $\mathrm{O}_{2}{ }^{-}$accumulations react with freshly synthesized NO, local HOONO concentration may become sufficient to assure its efficient transport to reactive sites as far as several cell diameters away (33). In the vicinity of certain reactive centers, HOONO may undergo homolytic cleavage to a hydroxyl free radical $(\mathrm{OH})$ and nitrogen dioxide free radical $\left(\mathrm{NO}_{2}\right)$, or heterolytic cleavage to a nitronium cation $\left(\mathrm{NO}_{2}{ }^{+}\right)$ and hydroxide anion $\left(\mathrm{OH}^{-} ; 33\right)$. Three of these cleavage products $\left(\mathrm{OH}, \mathrm{NO}_{2}\right.$ radicals, and $\left.\mathrm{NO}_{2}^{+}\right)$, are among the most reactive and damaging species in biological systems (33).

The most intriguing and clinically useful finding of this paper is that the high concentration of the SOD product $\mathrm{H}_{2} \mathrm{O}_{2}$ observed in SHR may have some short term beneficial effect by virtue of its profound vasodilation properties. However, long term exposure of biological systems to elevated $\mathrm{H}_{2} \mathrm{O}_{2}$ is not advised, since any free ferrous ion $\left(\mathrm{Fe}^{2+}\right)$ that escapes the iron transporter ferritin will rapidly convert $\mathrm{H}_{2} \mathrm{O}_{2}$ into $\mathrm{OH}$ radical (Fenton reaction), the most destructive oxygen radical species (34).

The enhanced production of cNOS derived $\mathrm{O}_{2}{ }^{-}$in prehypertensive SHR may contribute to the development of hyper- tension, especially because this defect precedes the increase in blood pressure in this genetic model of hypertension. Endothelium-dependent contractions have been described in young SHR before the development of manifest hypertension (35). Interestingly, these contractions could be abolished with an inhibitor of $\mathrm{O}_{2}^{-}$production. Intravenous injections of SOD reduced arterial blood pressure in SHR but not in WKY normotensive rats (36). Furthermore, a correlation between the expression of endothelium-dependent contractions and increase in arterial blood pressure has been reported in SHR (37). These findings suggest that an increased production of $\mathrm{O}_{2}{ }^{-}$may play a role in the development of high arterial tone in hypertension.

Whether $\mathrm{O}_{2}{ }^{-}$formed via cNOS in prehypertensive SHR serves this function remains to be determined. However, this study strongly supports the concept of a dysfunctional cNOS as a new source of reactive oxygen metabolites $(14,31)$. This cNOS-catalyzed formation of $\mathrm{O}_{2}^{-}$and its subsequent transformation into HOONO cleavage products, or its dismutation into $\mathrm{H}_{2} \mathrm{O}_{2}$ and Fenton reaction product $\mathrm{OH}$, may play a central role in the endothelial dysfunction and oxidative vascular injury described in a number of vascular diseases (38-42). Supplementation with $\mathrm{H}_{4} \mathrm{~B}$, perhaps in combination with L-arginine (43) and free radical scavenger treatment (36) may find a future role in preventing essential hypertension and its complications.

\section{Acknowledgments}

We thank Petra Hoefler for technical assistance.

This work was supported in part by the Swiss National Research Foundation grant 32-35541.91 (T.F. Lüscher), the Austrian Research Funds project 11301 (E.R. Werner, G. Werner-Felmayer), and the US Public Health Service grant HL-55397 (T. Malinski).

\section{References}

1. Furchgott, R.F. 1988. Endothelium dependent relaxation in systemic arteries. In Mechanisms of Vasodilatation. P.M. Vanhoutte, editor. Raven Press, Ltd., New York. 401-414.

2. Ignarro, L.J., G.M. Buga, K.S. Wood, R.E. Byrnes, and G. Chaudhuri. 1987. Endothelium-derived relaxing factor produced and released from artery and vein is nitric oxide. Proc. Natl. Acad. Sci. USA. 84:9265-9269.

3. Rees, D.D., R.M. Palmer, and S. Moncada. 1989. The role of endothelium-derived nitric oxide in the regulation of blood pressure. Proc. Nat. Acad. Sci. USA. 86:3375-3378.

4. Lüscher, T.F., and P.M. Vanhoutte. 1990. The endothelium: modulator of cardiovascular function. CRC Press, Inc., Boca Raton, FL. 228 pp.

5. Malinski, T., M. Kapturczack, J. Dayharsh, and D. Bohr. 1993. Nitric oxide synthase activity in genetic hypertension. Biochem. Biophys. Res. Commun. 194:654-658.

6. Panza, J.A., P.R. Casino, C.M. Kilcoyne, and A.A. Quyyumi. 1993. Role of endothelium-derived nitric oxide in the abnormal endothelium-dependent vascular relaxation of patients with essential hypertension. Circulation. 87: $1468-1474$.

7. Panza, J.A., P.R. Casino, D.M. Badar, and A.A. Quyyumi. 1995. Impaired endothelium-dependent vasodilation in patients with essential hypertension. Evidence that nitric oxide abnormality is not localized to a single signal transduction pathway. Circulation. 91:1732-1738.

8. Tschudi, M.R., S. Mesaros, T.F. Lüscher, and T. Malinski. 1996. Direct in situ measurement of nitric oxide in mesenteric resistance arteries. Increased decomposition by superoxide in hypertension. Hypertension (Dallas). 27:32-35.

9. Knowles, R.G., and S. Moncada. 1994. Mammalian nitric oxide synthase. Biochem. J. 298:249-258.

10. Pou, S., W.S. Pou, D.S. Bredt, S.H. Snyder, and G.M. Rosen. 1992. Generation of superoxide by purified brain nitric oxide synthase. J. Biol. Chem. 267: 24173-24176.

11. Klatt, P., K. Schmidt, D. Lehner, O. Glatter, H.P. Bachinger, and B. Mayer. 1995. Structural analysis of porcine brain nitric oxide synthase reveals a role for tetrahydrobiopterin and L-arginine in the formation of an SDS-resis- 
tant dimer. EMBO (Eur. Mol. Biol. Organ.) J. 14:3687-3695.

12. Mayer, B., and E.R. Werner. 1995. In search of a function for tetrahydrobiopterin in the biosynthesis of nitric oxide. Naunyn-Schmiedeberg's Arch. Pharmacol. 351:453-463.

13. Abou-Donia, M.M., J.A. Daniels, C.A. Nichol, and H.L. Viveros. 1983. Regulation of adrenocortical guanosine triphosphate cyclohydrolase and tetrahydrobiopterin in normal and spontaneously hypertensive rats. In Chemistry and Biology of Pteridines. J.A. Blair, editor. Walter de Gruyter and Co., New York. 783-787.

14. Cosentino, F., and Z.S. Katusic. 1995. Tetrahydrobiopterin and dysfunction of endothelial nitric oxide synthase in coronary arteries. Circulation. 91: $139-144$

15. Cosentino, F., J.C. Sill, and Z.S. Katusic. 1993. Role of superoxide anions in the mediation of endothelium-dependent contractions. Hypertension. 23:229-235.

16. Fridovich, I. 1978. The biology of oxygen radicals. Science. 201:875-880.

17. Malinski, T., and Z. Taha. 1992. Nitric oxide release from a single cell measured in situ by a porphyrinic-based microsensor. Nature. 358:676-678.

18. Malinski, T., and L. Czuchajowski. 1996. Nitric oxide measurements by electrochemical methods. In Methods of Nitric Oxide Research. M. Feelisch and J.S. Stamler, editors. John Wiley \& Sons Ltd., Chichester, UK. 319-339.

19. Mesaros, S., S. Grunfeld, A. Mesarosova, D. Bustin, and T. Malinski. 1997. Determination of nitric oxide saturated (stock) solution by chronoamperometry on a porphyrine microelectrode. Anal. Chim. Acta. 339:265-270.

20. Vreeke, M.S., and A. Heller. 1994. Diagnostic biosensor polymers. A.M. Usmani and N. Akmal, editors. In ACS Symposium Series 556. American Chemical Society, Washington D.C. 180-192.

21. Vreeke, M.S., R. Maidan, and A. Heller. 1992. Hydrogen peroxide and $\beta$-nicotinamide adenine dinucleotide sensing amperometric electrodes based on electrical connection of horseradish peroxidase redox centers to electrodes through a three-dimensional electron relaying polymer network. Anal. Chem. 64:3084-3090.

22. Gyllenhammer, H. 1987. Lucigenin chemiluminescence in the assessment of neutrophil superoxide production. J. Immunol. Methods. 97:209-213.

23. Werner-Felmayer, G., H. Prost, E.R. Werner, A. Philippu, and H. Wachter. 1993. Induction of GTP cyclohydrolase I by bacterial lipopolysaccharide in the rat. FEBS (Fed. Eur. Biochem. Soc.) Lett. 322:223-226.

24. Werner-Felmayer, G., E.R. Werner, D. Fuchs, A. Hausen, B. Mayer, G. Reibnegger, G. Weiss, and H. Wachter. 1993. $\mathrm{Ca}^{2+} /$ calmodulin-dependent nitric oxide synthase activity in the human cervix carcinoma cell line ME-180. Biochem. J. 289:357-361.

25. Kontos, H.A. 1985. Oxygen radicals in cerebral vascular injury. Circ. Res. 57:508-516.

26. Mohazzab, K.M., P.M. Kaminski, and M.S. Wolin. 1994. NADH oxidoreductase is a major source of superoxide anion in bovine coronary artery endothelium. Am. J. Physiol. 266:H2568-H2572.

27. Waldman, S.A., and F. Murad. 1987. Cyclic GMP synthesis and function. Pharmacol. Rev. 39:163-196.

28. Burke, T.M., and M.S. Wolin. 1987. Hydrogen peroxide elicits pulmonary arterial relaxation and guanylate cyclase activation. Am. J. Physiol. 252: H721-H732.

29. Salvemini, D., W. Radziszewski, V. Mollace, A. Moore, D. Willoughby, and J.R. Vane. Diphenylene iodonium, an inhibitor of free radical formation, inhibits platelet aggregation. 1991. Eur. J. Pharmacol. 199:15-18.

30. Stuehr, D.J., O.A. Fasehun, N.S. Kwon, S.S. Gross, J.A. Gonzalez, and R. Levi. 1991. Inhibition of macrophage and endothelial cell nitric oxide synthase by diphenylene iodonium and its analogs. FASEB (Fed. Am. Soc. Exp. Biol.) J. 5:98-103.

31. Pritchard, K.A., L. Groszek, D.M. Smalley, W.C. Sessa, M. Wu, P. Villalon, M.S. Wolin, and M.B. Stemerman. 1995. Native low-density lipoprotein increases endothelial cell nitric oxide synthase generation of superoxide anion. Circ. Res. 77:510-518

32. Kobayashi, K., and M. Miki. 1994. A direct demonstration of reaction of nitric oxide with superoxide anion by the use of pulse radiolysis. In Frontiers of Reactive Oxygen Species in Biology \& Medicine. K. Asada and T. Yoshikawa, editors. Elsevier Science BV, Amsterdam. 223-224.

33. Beckman, J.S., J. Chen, H. Ischiropoulos, and J.P. Crow. 1994. Oxidative chemistry of peroxynitrite. In Methods of Enzymology, Vol. 233, Part C, Oxygen Radicals in Biological Systems. L. Packer, editor. Academic Press, Inc., San Diego, CA. 229-240.

34. Halliwell, B., and J.M.C. Gutteridge. 1990. Role of free radicals and catalytic metal ions in human disease: an overview. In Methods of Enzymology, Vol. 186, Part B, Oxygen Radicals and Antioxidants. L. Packer and A. Glazer, editors. Academic Press, Inc., San Diego, CA. 1-85.

35. Jameson, M., F.X. Dai, T.F. Lüscher, J. Skopec, A. Diederich, and D. Diederich. 1993. Endothelium-derived contracting factors in resistance arteries of young spontaneously hypertensive rats before development of overt hypertension. Hypertension (Dallas). 21: 280-288.

36. Nakazono, K., N. Watanabe, K. Matsuno, J. Sasaki, T. Sato, and M. Inoue. 1991. Superoxide underlie the pathogenesis of hypertension? Proc. Natl. Acad. Sci. USA. 88:10045-10048.

37. Iwama, Y., T. Kato, M. Muramatsu, H. Asano, K. Shimizu, Y. Toki, Y. Miyazaki, K. Okumura, H. Hashimoto, T. Ito, and T. Satake. 1992. Correlation with blood pressure of the acetylcholine-induced endothelium-derived contracting factor in rat aorta. Hypertension (Dallas). 19:326-332.

38. Grisham, M.B., and J. McCord. 1986. Chemistry and cytotoxicity of reactive oxygen metabolites. In Physiology of Oxygen Radicals. A.E. Taylor, S. Matalon, P. Ward, editors. American Physiological Society, Bethesda, MD. 1-18.

39. Pryor, WA. 1994. Free radicals and lipid peroxidation: what they are and how they got that way. In Natural Antioxidants in Human Health and Disease. B. Frei, editor. Academic Press, Boston. 1-24.

40. Halliwell, B. 1994. Free radicals, antioxidants, and human disease: curiosity, cause, or consequence? Lancet (N. Am. Ed.). 344:721-724.

41. Suryaprabha, P., U.N. Das, P.S. Koratkar, P.S. Sangeetha, and G. Ramesh. 1990. Free radicals, lipid peroxidation and essential fatty acids in uncontrolled essential hypertension. Prostaglandins Leukot. Essent. Fatty Acids. 41:27-33.

42. Kumar, K., and U.N. Das. 1993. Are free radicals involved in the pathobiology of human essential hypertension? Free Rad. Res. Comms. 19:59-66.

43. Huk, I., J. Nanobashvili, C. Neumayer, A. Punz, M. Mueller, K. Afkhampour, M. Mittlboeck, U. Losert, P. Polterauer, E. Roth, et al. 1997. L-arginine treatment alters the kinetics of nitric oxide and superoxide release and reduces ischemia/reperfusion injury in skeletal muscle. Circulation. 96:667675 